\title{
Innovative Sources of Development Finance - Global Cooperation in the $21^{\text {st }}$ Century $^{*}$
}

\author{
Raghbendra Jha, ASARC \\ Australian National University
}

October 2002

\begin{abstract}
This paper argues that, in view of the resource crunch confronting many developing countries and the fall in ODA flows to them; new sources of development finance need to be found. We consider international taxes, fees and levies that could considerably augment aid flows to developing countries and some of which may have coincident beneficial effects. Estimates of the revenue yield from such taxes and levies are also presented. The paper proposes the establishment of a World Development Organization (WDO) to coordinate such effort. A formula for voting within the organization and another for disbursal of such aid are suggested.
\end{abstract}

JEL Codes: F02, F35, H23, H87

Keywords: Global taxes, fees and charges, World Development Organization

All correspondence to:

Prof. Raghbendra Jha, Australia South Asia Research Centre, Research School of Pacific and Asian Studies, Australian National University, Canberra, ACT 0200, Australia

Phone: +61261252683

Fax: $\quad+61261250443$

Email: r.jha@anu.edu.au

\footnotetext{
* I would like to thank Matthew Odedokun and Mark McGillivray for helpful comments and Anurag Sharms for research assistance. All opinions and any errors are mine.
} 


\section{Introduction}

In 2000 the UN set forward a set of millennium development goals (MDG) to be attained by 2015. Starting from a base of 1990 targets included halving income poverty and hunger, achieving universal primary education and gender equality, reducing under- 5 mortality by two-thirds and maternal mortality by three quarters, reversing the spread of HIV-AIDS, and halving the proportion of people without access to safe water by ${ }^{1} 2015$. Targets were later revised -e.g., for poverty the base line was specified. Also, in addition to the head-count index, the expanded set of targets includes the poverty gap ratio and a regional disaggregation is given.

What has been the progress towards these targets? According to Vandemoortele (2002) if the 1980s were "the lost decade of development" the 1990s should go down in history as the "decade of broken promises". On average, only one MDG target - that of halving the proportion of people without access to safe water by 2015 - is on track. However, even here the current rate of progress may not be sustainable as many countries face acute water shortages in the near future. Not only was global progress inadequate in the 1990s - much of it bypassed the poor even as inequality both within and across countries increased. Thus average attainments are not good enough.

Further, some of the poorest developing countries are facing severe resource crunch. The fiscal and current account deficits (the so-called twin deficits problem) are unsustainable in many developing countries (Jha (2001)). Moreover, there has been a virtual explosion of the debt burden. In 1998, the total debt stock of LDCs amounted to US\$ 154 billion. This is almost four times as high as the corresponding figure in 1980 . For every single LDC, the debt stock shows a steady and significant

The details are available on http://www.oecd.org//dac/Indicators/htm/goals.htm 
increase since 1980. Furthermore, debt servicing is placing an immense burden: in some HIPC-LDCs debt servicing forms a share of the government's budget comparable to that on education. Ironically, in the face of such resource in developing countries there has been considerable decline in ODA disbursements over the 1990s with the average disbursal well below the $0.7 \%$ of GNP target envisaged by the DAC.

Against this background some authors, particularly Burnside and Dollar (2000) (henceforth BD), have expressed doubts about the effectiveness of aid. If aid is ineffective, it does not matter if it is not forthcoming in large magnitudes. In their model aid contributes positively to economic growth, but only in good policy environments. However, Hansen and Tarp (2000, 2001) (henceforth HT) argue that aid accelerates growth whenever growth is driven by capital accumulation and that aid effectiveness is highly sensitive to the choice of estimator. In the HT regressions aid increases growth (primarily through investment) and this effect is not conditional upon policy - particularly the policy index established by BD. Hence there is some evidence to suggest that aid remains an effective instrument ${ }^{2}$ for enhancing economic growth in the poorest countries.

It is important, then, to augment aid resources - particularly at the global level. The present paper examines international avenues for garnering resources for developing countries. In section II we evaluate some of these proposals. Following

\footnotetext{
${ }^{2}$ Collier and Dehn (2001) argue that apart from the problem of sensitivity to choice of sample (discussed in HT) one should also consider another factor ignored by BD, i.e, shocks. Collier and Dehn find that for 56 countries over the period 1970-93 negative effects of trade shocks have long-term effects on output. If shocks have effects on growth their omission from the analysis of aid effectiveness is potentially problematic. If macroeconomic policy deteriorates during shocks the result that aid is more effective the better is macroeconomic policy is spurious since policy might simply be proxying shocks. This is most likely in case of weak institutions. The level of initial aid and its comovement with shocks would be important. Collier and Dehn compute an index of shock and having controlled for these they agree with BD. However as HT emphasize, the Collier and Dehn result is sensitive to the measure of export shock used.
} 
that we examine the issue of tax administration in section III. Once the revenues have been collected one would need to address the issue of their disbursal among developing countries. Section IV considers the modus operandi of this. Section V concludes.

\section{International Measures to Augment Aid Resources}

Measures to augment aid transfers to developing countries fall into two broad categories: Universal and Non-universal. The latter include bilateral flows as well as those through organizations such as the IMF, the IBRD, regional development banks and the like. In this paper we focus exclusively on universal or near-universal measures. One organization that is capable of such reach is the United Nations. In the past UN aid flows have been distinguished by four characteristics. Such aid has been (i) concessional, i.e., in the form, entirely or in large part, of grants or soft loans; (ii) untied to the purchase of goods and services from any particular donor; (iii) not subject to conditionality as are IMF loans; and (iv) extended regardless of the political orientation of the recipient government. But as Mendez (1992) mentions the hard budget constraint faced by the UN, largely because of US arrears to the $\mathrm{UN}^{3}$ has led to aid flows to slow down to a mere trickle.

Over the years several suggestions for global charges and fees have been made. Table 1 list twenty-one such suggestions.

\section{Table 1}

Twenty-one Recent Suggestions for Global Revenue

\begin{tabular}{|l|l|}
\hline 1. & $\begin{array}{l}\text { A tax on part or all of international financial transactions. In some versions } \\
\text { a tax on bond turnover or on derivatives is added. This is the so-called } \\
\text { Tobin tax or currency transactions tax (CTT). A variant is a cross border } \\
\text { capital tax. }\end{array}$ \\
\hline 2. & A general tax on the sum of exports and imports. \\
\hline 3. & $\begin{array}{l}\text { Taxes on specified traded goods such as petroleum, more generally a } \\
\text { carbon tax. }\end{array}$ \\
\hline
\end{tabular}

\footnotetext{
${ }^{3}$ As of 30 June 2002 the US owed $\$ 446$ million toward the UN's general budget (67\% of total); $\$ 655$ million towards peacekeeping ( $57 \%$ of total) and $\$ 1.117$ billion overall ( $55 \%$ of the total).
} 


\begin{tabular}{|l|l|}
\hline 4. & A tax on the international arms trade. \\
\hline 5. & Surcharges on post and telecommunications revenue. \\
\hline 6. & An international lottery. \\
\hline 7. & $\begin{array}{l}\text { A surcharge on domestic taxation. This could be a surcharge on the highest } \\
\text { income tax bracket. }\end{array}$ \\
\hline 8. & $\begin{array}{l}\text { Earmarking of some part of national or local taxes, e.g., on luxuries, or } \\
\text { surcharges on them. }\end{array}$ \\
\hline 9. & Parking charges for satellites placed in the geostationary orbit. \\
\hline 10. & Royalties on minerals mined in international waters. \\
\hline 11. & Charges for exploration in or exploitation of Antarctica. \\
\hline 12. & Charges for fishing in international waters. \\
\hline 13. & Charges for the use of the electromagnetic spectrum. \\
\hline 14. & A tax on international aviation. A variant is a tax on kerosene. \\
\hline 15. & A tax or charge on international shipping. \\
\hline 16. & Pollution charges, e.g., a carbon tax or charges for dumping at sea. \\
\hline 17. & A tax on traded pollution permits. \\
\hline 18. & A voluntary local tax paid to a central global agency. \\
\hline 19. & $\begin{array}{l}\text { A new issue of SDRs, distributed to the poorest developing countries (or } \\
\text { used for providing urgently needed global pubic goods (GPG). }\end{array}$ \\
\hline 20. & Sale of part of the IMF gold stock. \\
\hline 21. & A tax on the Internet or a bit tax. \\
\hline
\end{tabular}

Source: ODI, UK and author's compilation.

We now discuss some of the key proposals.

\section{II.1 Carbon taxes}

The carbon tax is visualized as an indirect tax on the carbon content of oil, coal and natural gas on a global level as distinct from carbon taxes being imposed unilaterally by some countries. Taxes based on the carbon content of the fuel consumed should be distinguished from other energy taxes. A true energy tax, or Btu tax, places the levy on the amount energy consumed. An ad valorem tax, taxes the final product, such as gasoline or heating fuel.

A UN paper estimates that a tax amounting to $\$ 21$ per ton of carbon (the equivalent of 4.8 cents per gallon of gasoline) would yield $\$ 125$ billion annually. Cooper (1998) estimates that the first round of Kyoto commitments would require a $\$ 23$ per ton tax. Over $20 \%$ of the tax yields would originate in the US. 
An attendant benefit of the tax is its Pigovian character and help in reducing carbon emissions ${ }^{4}$. According to the IPCC, taxes of $\$ 100$ per ton of carbon could reduce emissions up to 5 billion tons by 2020 . This would still leave the world with more emissions than at present. Higher tax will yield more revenue and lead to a higher drop in carbon levels. These calculations assume that tax is the only deterrent. However, the elasticity of the response to the tax may be high as newer technologies become commercially viable with the long run elasticity being significantly higher than the short-run.

Support for an international "carbon tax" has been growing since the 1992 UN Earth Summit focused international attention on the damage to the environment caused by excessive use of fossil fuels worldwide. The release of greenhouse gases, mainly carbon dioxide from fossil fuels, contributes to global warming and climate change. The main energy sources that would be affected by a carbon tax include coal, petroleum, kerosene and natural gas. The tax would be reflected in an increase in their price, at a level based on the capacity of each type of fuel to emit carbon dioxide: the higher the carbon content, the higher the minimum tax rate. Fuel vendors would likely collect the tax. Tax authorities would levy carbon taxes directly on the sale of carbon fuels, thus collection of carbon taxes would be as easy as value-added taxes or sales taxes. Because VAT taxes are already in widespread use, and because sellers almost everywhere use computerized systems, adding this collection item would not impose much difficulty or extra cost. To the extent that the tax is imposed on internationally

\footnotetext{
4 The tax uses the "polluter-pays" principle. According to the first UNEP expert group's study, a tax on the amount of oil or refined products discharged into the ocean would induce offenders to reduce polluting emissions and, to the extent, that total elimination was uneconomic, produce revenues for international purposes. Clearly polluters who install antipollution devices should be taxed at a lower rate than those who do not. Another example is a tax on carbon fuels (the carbon tax) to internalize the economic social costs of deforestation on producers of CFCs to internalize the adverse effects on the ozone layer, and on the other generators of external costs. Carbon taxes are already in place in a number of Western countries and such taxation could be extended to the international level.
} 
traded items, customs officials would appear to be better suited for collecting the taxes. Such taxes can be collected at source or destination or both. European experience suggests a collection cost of less than one percent and a UN paper affirms that in most cases "administrative and compliance costs of the extra taxation would be negligible.” (European Commission (2002)).

Distributionally the tax will be regressive, ceteris paribus, since fuel bills typically form a disproportionately larger portion of the budget of low-income groups as compared to high-income groups. Further pressure on firewood for fuel would rise as fossil fuels would become even more out of the reach for the poor. But there could be ameliorating factors as well - particularly if the yield of the tax could help finance programs targeted toward the poor.

The carbon tax's main problem is not technical but political - the staunch opposition of a number of powerful global industries. However, six European states ${ }^{5}$, five of them EU members - Denmark, Finland, Germany, the Netherlands, Norway and Sweden - have already levied energy/carbon taxes at the national level. More EU members are inclined in this direction. Thus, a political bloc is forming that could steadily overcome opponents and implement the tax.

\section{II.2 A Currency Transactions Tax (CTT)}

A well-known measure to augment resources for transfers to developing countries is a currency transactions tax (CTT) or the Tobin tax after James Tobin, who first articulated this measure in 1972 and again in 1978, although some trace it to Keynes. The CTT was initially proposed to discourage excessive speculation on foreign exchange markets. This would give greater room to central banks to pursue domestic

\footnotetext{
${ }^{5}$ Paul and Wahlberg (2001), provide a useful review of the coalitions for and against this tax. The tax has been popular in the EU, but not in Britain (which fears that this would compromise British competitiveness vis a vis the EU and the US) or the US. However the British Advisory Committee on Business and the Environment has advocated exploring the use of this tax.
} 
monetary policy in a world of flexible exchange rates. Its potential use to finance development objectives came much later on. In the original proposal all foreign exchange transactions in currency were to be taxed. Gradually this was expanded to include assets - such as derivatives and T-bills - to which investors would escape in the event of such a tax.

It is difficult to estimate the revenue potential of the tax since it is not known how liquidity in foreign exchange markets will react to its imposition. On the face of it revenue yields could be enormous. The average value of foreign exchange dealings rose from $\$ 15$ billion per day in 1973 to $\$ 1.49$ trillion in 1998 before dropping to $\$ 1.2$ trillion in 2001 (Table 2). Spot transactions as well as foreign exchange swaps increased continuously since 1989 to 1998 . The launch of the Euro led to an elimination of intra-EURO currency swaps and a drop in the turnover in 2001.A straightforward application of a tax rate to these magnitudes is subject to the caveat that we have no estimates of the possible liquidity effects. However, it is unlikely that a small tax would have serious liquidity impact. Paul and Wahlberg (2001) estimate that a tax of $0.2 \%$ with a hypothetical $50 \%$ reduction in transactions would result in annual revenue of about $\$ 300$ billion. Even a $0.01 \%$ tax allowing for substantial evasion would have yielded at least $\$ 12$ million in 1996. (ODI (1996)).

\begin{tabular}{|l|l|l|l|l|l|}
\hline \multicolumn{7}{|c|}{$\begin{array}{l}\text { Table 2 } \\
\text { Global Foreign Exchange Market Turnover } \\
\text { Daily averages in billions of US dollars }\end{array}$} \\
\hline Instrument & 1989 & 1992 & 1995 & $1998^{2}$ & 2001 \\
\hline Spot transactions & 317 & 394 & 494 & 568 & 387 \\
\hline Outright forwards & 27 & 58 & 97 & 128 & 131 \\
\hline $\begin{array}{l}\text { Foreign Exchange } \\
\text { swaps }\end{array}$ & 190 & 324 & 546 & 734 & 656 \\
\hline $\begin{array}{l}\text { Estimated gaps in } \\
\text { reporting }\end{array}$ & 56 & 44 & 53 & 60 & 36 \\
\hline $\begin{array}{l}\text { Total "traditional" } \\
\text { turnover }\end{array}$ & 590 & 820 & 1190 & 1490 & 1210 \\
\hline $\begin{array}{l}\text { Turnover at April } \\
\text { 2001 exchange rates }\end{array}$ & 570 & 750 & 990 & 1400 & 1210 \\
\hline
\end{tabular}


1. Adjusted for local and cross-border double counting. 2. Revised. 3. Non-US dollar legs of foreign currency transactions were converted into original currency amounts at average exchange rates for April of each survey year and then reconverted into US dollar amounts at average April 2001 exchange rates.

Source: BIS (2002)

The distribution of the yield of the tax is, however, likely to be rather uneven.

Table 3 indicates this. Almost half the transactions are denominated in the US dollar.

Developing country currencies fall in the "other" group, which accounts for no more than $11 \%$ of the transactions. Hence any credible CTT must inevitably be levied in the markets of developed countries.

\begin{tabular}{|c|c|c|c|c|c|}
\hline \multicolumn{6}{|c|}{$\begin{array}{c}\text { Table } 3 \\
\begin{array}{c}\text { Currency Distribution of reported global Foreign Exchange Market Turnover } \\
\text { Percentage Shares of average daily turnover in April }\end{array} \\
\end{array}$} \\
\hline Currency & 1989 & 1992 & 1995 & $1998^{2}$ & 2001 \\
\hline US dollar & 90 & 82.0 & 83.3 & 87.3 & 90.4 \\
\hline Euro & & & & & 37.6 \\
\hline Deutsche Mark ${ }^{3}$ & 27 & 39.6 & 36.1 & 30.1 & \\
\hline French Franc & 2 & 3.8 & 7.9 & 5.1 & \\
\hline $\begin{array}{l}\text { ECU and other EMS } \\
\text { currencies }\end{array}$ & 4 & 11.8 & 15.7 & 17.3 & \\
\hline Japanese yen & 27 & 23.4 & 24.1 & 20.2 & 22.7 \\
\hline Pound sterling & 15 & 13.6 & 9.4 & 11.0 & 13.2 \\
\hline Swiss Franc & 10 & 8.4 & 7.3 & 7.1 & 6.1 \\
\hline Canadian dollar & 1 & 3.3 & 3.4 & 3.6 & 4.5 \\
\hline Australian dollar & 2 & 2.5 & 2.7 & 3.1 & 4.2 \\
\hline Swedish krona $^{4}$ & & 1.3 & 0.6 & 0.4 & 2.6 \\
\hline Hong Kong dollar ${ }^{4}$ & & 1.1 & 0.9 & 1.3 & 2.3 \\
\hline Norwegian krone $^{4}$ & & 0.3 & 0.2 & 0.4 & 1.5 \\
\hline Danish krone $^{4}$ & & 0.5 & 0.6 & 0.4 & 1.2 \\
\hline Singapore dollar ${ }^{4}$ & & 0.3 & 0.31 & 1.2 & 1.1 \\
\hline South African rand ${ }^{4}$ & & 0.3 & 0.2 & 0.5 & 1.0 \\
\hline Mexican Peso $^{4}$ & & & & 0.6 & 0.9 \\
\hline Korean won ${ }^{4}$ & & & & 0.2 & 0.8 \\
\hline New Zealand dollar ${ }^{4}$ & & 0.2 & 0.2 & 0.3 & 0.6 \\
\hline Polish zloty ${ }^{4}$ & & & & 0.1 & 0.5 \\
\hline Brazilian real $^{4}$ & & & & 0.4 & 0.4 \\
\hline Russian rouble $^{4}$ & & & & 0.3 & 0.4 \\
\hline Taiwan dollar ${ }^{4}$ & & & & 0.1 & 0.3 \\
\hline Chilean peso ${ }^{4}$ & & & & 0.1 & 0.2 \\
\hline Czech koruna $^{4}$ & & & & 0.3 & 0.2 \\
\hline Indian rupee 4 & & & & 0.1 & 0.2 \\
\hline
\end{tabular}




\begin{tabular}{|l|l|l|l|l|l|}
\hline Thai baht $^{4}$ & & & & 0.2 & 0.2 \\
\hline Malaysian ringgit $^{4}$ & & & & 0.0 & 0.1 \\
\hline Saudi riyal & & & & 0.1 & 0.1 \\
\hline Other currencies & & & 7.1 & 8.2 & 6.7 \\
\hline All currencies & 2200 & 200 & 200 & 200 & 200 \\
\hline
\end{tabular}

1. Because two currencies are involved in each transaction, the sum of the percentage shares of individual currencies totals $200 \%$ instead of $100 \%$. The figures relate to reported "net-net" turnover, i.e., they are adjusted for both local and cross-border double counting, except for 1989 data, which are available only on a "gross-gross" basis. 2. Revised. 3. Data for April 1989 exclude domestic trading involving the Deutsche mark in Germany. 4. For 1992-98, the data cover local home currency trading only.

Source: BIS (2002)

Table 4 reports the currency turnover in currency pairs. The dominant role of the developed country currencies is clear. The following eight currency pairs (USD/EUR, USD/JPY, USD/GBP, USD/CHF, USD/CAD, EUR/GBP, EUR/CHF and EUR/JPY) accounted for $76 \%$ of the daily foreign exchange turnover in April 2001, with the first two pairs alone representing 50\%. Hence, revenue from the CTT will be concentrated in the hands of a few countries/currencies.

\begin{tabular}{|c|c|c|c|c|c|c|c|c|}
\hline & $\begin{array}{l}\text { Reporte } \\
\text { aily avera }\end{array}$ & $\begin{array}{l}\text { Foreig } \\
\text { es in A }\end{array}$ & $\begin{array}{l}\mathrm{Ta} \\
\text { Exchang } \\
\text { ril, in billi }\end{array}$ & $\begin{array}{l}\text { ble } 4 \\
\text { Turno } \\
\text { ons of }\end{array}$ & $\begin{array}{l}\text { er by Cur } \\
\mathrm{S} \text { dollars }\end{array}$ & $\begin{array}{l}\text { ency P } \\
\text { nd per }\end{array}$ & $\begin{array}{l}\text { rs }^{1} \\
\text { ntages }\end{array}$ & \\
\hline Currency & 19 & & 19 & & 199 & & 20 & \\
\hline Pair & Amount & $\begin{array}{l}\% \% \\
\text { share }\end{array}$ & Amount & $\begin{array}{l}\% \\
\text { share }\end{array}$ & Amount & $\begin{array}{l}\% \\
\text { share }\end{array}$ & Amount & $\begin{array}{l}\% \\
\text { share }\end{array}$ \\
\hline USD/EUR & & & & & & & 352 & 30 \\
\hline USD/DEM & 192 & 25 & 254 & 22 & 291 & 20 & & \\
\hline USD/FRF & 19 & 2 & 51 & 4 & 58 & 4 & & \\
\hline USD/XEU & 13 & 2 & 18 & 2 & 17 & 1 & & \\
\hline $\begin{array}{r}\text { USD/Other } \\
\text { EMS }\end{array}$ & 43 & 6 & 104 & 9 & 176 & 12 & & \\
\hline USD/JPY & 155 & 20 & 242 & 21 & 257 & 18 & 230 & 20 \\
\hline USD/GBP & 77 & 10 & 78 & 7 & 118 & 8 & 125 & 11 \\
\hline USD/CHF & 49 & 6 & 61 & 5 & 79 & 5 & 57 & 5 \\
\hline USD/CAD & 25 & 3 & 38 & 3 & 50 & 3 & 50 & 4 \\
\hline USD/AUD & 18 & 2 & 29 & 3 & 42 & 3 & 47 & 4 \\
\hline USD/oth & 48 & 6 & 72 & 6 & 172 & 12 & 197 & 17 \\
\hline EUR/JPY & & & & & & & 30 & 3 \\
\hline EUR/GBP & & & & & & & 24 & 2 \\
\hline EUR/CHF & & & & & & & 12 & 1 \\
\hline EUR/oth & & & & & & & 22 & 2 \\
\hline
\end{tabular}




\begin{tabular}{|l|l|l|l|l|l|l|l|l|}
\hline DEM/JPY & 18 & 2 & 24 & 2 & 24 & 2 & & \\
\hline DEM/GBP & 23 & 3 & 21 & 2 & 31 & 2 & & \\
\hline DEM/CHF & 13 & 2 & 18 & 2 & 18 & 1 & & \\
\hline DEM/FRF & 10 & 1 & 34 & 3 & 10 & 1 & & \\
\hline DEM/XEU & 6 & 1 & 6 & 1 & 3 & 0 & & \\
\hline $\begin{array}{l}\text { DEM/Oth } \\
\text { EMS }\end{array}$ & 21 & 3 & 38 & 3 & 35 & 2 & & \\
\hline DEM/Oth & 20 & 3 & 16 & 1 & 18 & 1 & & \\
\hline $\begin{array}{l}\text { OthEMS/ } \\
\text { OtheEMS }\end{array}$ & 3 & 0 & 3 & 0 & 5 & 0 & & 24 \\
\hline $\begin{array}{l}\text { Other } \\
\text { currency } \\
\text { pairs }\end{array}$ & 25 & 3 & 30 & 3 & 31 & 2 & 24 & 2 \\
\hline $\begin{array}{l}\text { All } \\
\text { currency } \\
\text { pairs }\end{array}$ & 778 & 100 & 1137 & 100 & 1430 & 100 & 1173 & 100 \\
\hline 1. Adjusted & & & & & & & & \\
\hline
\end{tabular}

1. Adjusted for local and cross-border double counting. 2. Revised. 3. The data cover local home currency trading only.

Source: BIS (2002)

Although the US dollar dominates the currency markets, as Table 5 indicates, the US, as a geographical entity, is not the largest currency market. London is the largest single market and it along with other European markets commands an important share in the foreign exchange market turnover. These markets have the further advantage that they are broadly in the same time zone and provide links between the Asian and North American markets. The CTT would be highly progressive since there would be a shift of resources from the players in financial markets, mainly situated in affluent countries, towards the developing countries.

\begin{tabular}{|l|l|l|l|l|l|l|l|l|l|l|l|}
\hline \multicolumn{10}{|c|}{ Table 5 } \\
\multicolumn{10}{|c|}{$\begin{array}{c}\text { Geographical Distribution of Global Reported Foreign Exchange Market Turnover } \\
\text { Daily averages in April, in billions of US dollars and percentages }\end{array}$} \\
\hline Country & \multicolumn{2}{|c|}{1989} & \multicolumn{2}{c|}{1992} & \multicolumn{2}{c|}{1995} & \multicolumn{2}{c|}{1998} & \multicolumn{2}{c|}{2001} \\
\hline Australia & 29 & 4 & 29 & 2.7 & 40 & 2.5 & 47 & 2.4 & 52 & 3.2 \\
\hline Austria & & & 4 & 0.4 & 13 & 0.8 & 11 & 0.6 & 8 & 0.5 \\
\hline Bahrain & 3 & 0.4 & 4 & 0.4 & 3 & 0.2 & 2 & 0.1 & 3 & 0.2 \\
\hline Belgium & 10 & 1.4 & 16 & 1.5 & 28 & 1.8 & 27 & 1.4 & 10 & 0.6 \\
\hline Brazil & & & & & & & & 5 & 0.3 & 5 & 0.3 \\
\hline Canada & 15 & 2.1 & 22 & 2 & 30 & 1.9 & 37 & 1.9 & 42 & 2.6 \\
\hline Chile & & & & & & & 1 & 0.1 & 2 & 0.1 \\
\hline China $^{2}$ & & & & & & & 0 & 0 & 0 & 0 \\
\hline Colombia & & & & & & & & & 0 & 0 \\
\hline
\end{tabular}




\begin{tabular}{|c|c|c|c|c|c|c|c|c|c|c|}
\hline $\begin{array}{l}\text { Czech } \\
\text { Republic }\end{array}$ & & & & & & & 5 & 0.3 & 2 & 0.1 \\
\hline Denmark & 13 & 1.8 & 27 & 2.5 & 31 & 2 & 27 & 1.4 & 23 & 1.4 \\
\hline Finland $^{3}$ & 3 & 0.4 & 7 & 0.7 & 5 & 0.3 & 4 & 0.2 & 2 & 0.1 \\
\hline France & 23 & 3.2 & 33 & 3.1 & 58 & 3.7 & 72 & 3.7 & 48 & 3.0 \\
\hline Germany & & & 55 & 5.1 & 76 & 4.8 & 94 & 4.8 & 88 & 5.4 \\
\hline Greece & 0 & 0 & 1 & 0.1 & 3 & 0.2 & 7 & 0.4 & 5 & 0.3 \\
\hline Hong Kong & 49 & 6.8 & 60 & 5.6 & 90 & 5.7 & 79 & 4 & 67 & 4.1 \\
\hline Hungary & & & & & & & 1 & 0.1 & 1 & 0 \\
\hline India & & & & & & & 2 & 0.1 & 3 & 0.2 \\
\hline Indonesia & & & & & & & 2 & 0.1 & 4 & 0.2 \\
\hline Ireland & 5 & 0.7 & 6 & 0.6 & 5 & 0.3 & 10 & 0.5 & 8 & 0.5 \\
\hline Israel & & & & & & & & & 1 & 0.0 \\
\hline Italy & 10 & 1.4 & 16 & 1.5 & 23 & 1.5 & 28 & 1.4 & 17 & 1 \\
\hline Japan $^{4}$ & 111 & 15.5 & 120 & 11.2 & 161 & 10.2 & 136 & 6.9 & 147 & 9.1 \\
\hline Korea & & & & & & & 4 & 0.2 & 10 & 0.6 \\
\hline Luxembourg & & & 13 & 1.2 & 19 & 1.2 & 22 & 1.1 & 13 & 0.8 \\
\hline Malaysia & & & & & & & 1 & 0.1 & 1 & 0.1 \\
\hline Mexico & & & & & & & 9 & 0.5 & 9 & 0.5 \\
\hline Netherlands & 13 & 1.8 & 20 & 1.9 & 26 & 1.7 & 41 & 2.1 & 30 & 1.9 \\
\hline $\begin{array}{l}\text { New } \\
\text { Zealand }\end{array}$ & & & 4 & 0.4 & 7 & 0.4 & 7 & 0.4 & 4 & 0.2 \\
\hline Norway & 4 & 0.6 & 5 & 0.5 & 8 & 0.5 & 9 & 0.5 & 13 & 0.8 \\
\hline Peru & & & 0 & 0 & 0 & 0 & 0 & 0 & 0 & 0 \\
\hline Philippines & & & & & & & 1 & 0.1 & 1 & 0.1 \\
\hline Poland & & & & & & & 3 & 0.2 & 8 & 0.5 \\
\hline Portugal & 1 & 0.1 & 1 & 0.1 & 2 & 0.1 & 4 & 0.2 & 2 & 0.1 \\
\hline Russia & & & & & & & 7 & 0.4 & 10 & 0.6 \\
\hline $\begin{array}{l}\text { Saudi } \\
\text { Arabia }\end{array}$ & & & & & & & 2 & 0.1 & 2 & 0.1 \\
\hline Singapore & 55 & 7.7 & 74 & 6.9 & 105 & 6.7 & 139 & 7.1 & 101 & 6.2 \\
\hline $\begin{array}{l}\text { Slovak } \\
\text { Republic }\end{array}$ & & & & & & & & & 1 & 0 \\
\hline Slovenia & & & & & & & & & 0 & 0 \\
\hline South Africa & & & 3 & 0.3 & 5 & 0.3 & 9 & 0.5 & 10 & 0.6 \\
\hline Spain & 4 & 0.6 & 12 & 1.1 & 18 & 1.1 & 19 & 1.0 & 8 & 0.5 \\
\hline Sweden & 13 & 1.8 & 21 & 2 & 20 & 1.3 & 15 & 0.8 & 24 & 1.5 \\
\hline Switzerland & 56 & 7.8 & 66 & 6.1 & 87 & 5.5 & 82 & 4.2 & 71 & 4.4 \\
\hline Taiwan & & & & & & & 5 & 0.3 & 4 & 0.2 \\
\hline Thailand & & & & & & & 3 & 0.2 & 2 & 0.1 \\
\hline Turkey & & & & & & & & & 1 & 0.1 \\
\hline UK & 184 & 25.6 & 291 & 27.0 & 464 & 29.5 & 637 & 32.5 & 504 & 31.1 \\
\hline US & 115 & 16 & 167 & 15.5 & 244 & 15.5 & 351 & 17.9 & 254 & 15.7 \\
\hline Total $^{4}$ & 718 & 100 & 1076 & 100 & 1572 & 100 & 1958 & 100 & 1618 & 100 \\
\hline \multicolumn{11}{|c|}{$\begin{array}{l}\text { 1. Adjusted for local double counting ("net gross"). Estimated coverage of the foreign } \\
\text { exchange market ranged between } 90 \% \text { and } 100 \% \text { in most countries. } 3 \text {. Data only } \\
\text { cover spot transactions. } 2 \text {. Data for } 1992 \text { not adjusted for local double counting. } \\
\text { 4. Revised for } 1998 \text {. }\end{array}$} \\
\hline
\end{tabular}




\section{Source: BIS (2002)}

The CTT has found support from a number of quarters. Apart from Tobin, key supporters include Eichengreen, Tobin and Wyplosz (1995) Kaul, Grunberg and Stern (1999), Frankel (1995), Kenen (1995), and Griffith-Jones (1995). Major opponents include BIS (2001), the IMF and central banks of developed countries ${ }^{6}$. France during the Miterrand Presidency was an advocate; several developing countries including India and Malaysia have advocated use of this tax.

Given the immense revenue potential of this tax, its mechanics need deeper analysis. Interest in the CTT has fluctuated over the years. It has peaked during periods of turmoil in currency markets - say the European, Mexican, East Asian, Argentine and Russian crises - and ebbed once the crises have been resolved. However, with increasing frequency of crises in currency markets, not to speak of the long drawn out human costs in the countries going through such crises, interest in this proposal seems to be persisting now.

By definition almost, a unilateral CTT will lead to movement outside the markets of the country imposing it. If the country were to impose this tax on all branches of its banks anywhere in the world, business would move to other banks. Thus imposed unilaterally, a Tobin tax is almost completely ineffectual.

\footnotetext{
${ }^{6}$ Central banks have traditionally been averse to the Tobin tax. For instance BIS(2001) carries a report on creating financial market stability by Eva Srejber Second Deputy Governor of the Sveriges Riksbank (the central bank of Sweden). She argues that by linking together the national credit and payment markets, so that payments in one currency can be exchanged for payments in another currency, serves a useful purpose. She contends that the Tobin tax would not be useful since it does not solve the fundamental problem, namely incorrect assessments of credit and risks and the lack of capital in the banks to cover losses. If a country's financial markets are facing excessive volatility this is merely singling fundamental problems with monetary and fiscal policy. While this may be true, this does not reduce the attractiveness of the Tobin tax from the point of view of giving monetary authorities more space and time to make important decisions. Another major opponent is the IMF which, by moving aggressively in the direction of capital account convertibility, is leading the way toward greater exchange rate volatility.
} 
If all countries imposed the Tobin tax then foreign exchange transactions might be disguised as transactions in T-bills. If T-bills are also taxed then investors might move into stocks and so on. Where we would stop would depend on the transactions cost of moving into more complex assets as compared to the liability of paying the Tobin tax. In any case, this would bring in some inefficiency in the system, as people would expend real resources to get around this difficulty.

A major advantage accompanying is that by reducing exchange rate volatility a CTT can lend much needed policy space to central banks - particularly of developing countries. Developing country currencies are being inexorably moved towards a fixed exchange rate regime or, more likely, a full float. However, in today's world of high capital mobility, even the minor exercise of policy autonomy can produce major exchange market pressures. Attempts to peg the exchange rate can be defeated by rational and self-fulfilling attacks.

With flexible exchange rates, the fact that exchange rates are excessively volatile in a floating exchange rate regime has been known at least since Dornbusch (1976). During the Bretton Woods System the effectiveness of controls was buttressed by restrictions on international banking legislated in response to the Great Depression and by the fact that international bond markets had not yet recovered from the defaults of the 1930s. These controls softened the tradeoff between domestic objectives and defence of the exchange rate peg. Though never impermeable and progressively les effective as time passed, they reduced the cost of defending a currency peg and provided breathing space for governments to consult prior to devaluations.

There was a major structural shift following the abandonment of Bretton Woods system. In the case of developing countries the costs of excessive exchange 
rate volatility are now much greater and the conduct of any semblance of an independent monetary policy becomes very difficult ${ }^{7}$ as this would require these countries to commit a substantial portion of their foreign exchange reserves, earned through productive activities like exports or remittances, to trying to smoothen exchange rate movements. To this should be added the cost of keeping interest rates high in order to attract foreign capital. The resultant output loss has been termed "quasi-fiscal" costs and has been estimated by Calvo and Reinhart (2000) to be as high as $0.5 \%$ of GDP for some Latin American countries ${ }^{8}$. That the CTT could garner considerable resources while simultaneously reducing exchange rate volatility is a powerful argument in its favour.

In this vein Eichengreen, Tobin and Wyplosz (1995) argue that while most economists are instinctively sceptical about taxing international financial transactions as a way to enhance the operation of the international monetary system they react differently when the question is posed differently - should developing countries liberalize their capital accounts immediately. There is considerable agreement now that capital account liberalization must take place in steps. Full liberalization must necessarily await sufficient development of the domestic financial system, attainment of credibility in international financial markets and sufficient macroeconomic stability. Scholte (2002) argues that taming transworld financial flows must rank as one of the top priorities of governance in an emergent global polity. Lack of

\footnotetext{
7 Thus George Soros wrote in an article in the Washington Post on 21 December, 1997: "South Korea and other Asian countries - like Mexico in 1994-95 - are being punished for offences they did not commit. They have inflation and government budgets under control. They are not sinners, but victims of a flawed international exchange rate system that, under U.S. leadership gives the mobility of capital priority over all other considerations. It is simply too easy for banks, governments, businesses and speculators to buy and sell huge blocks of a country's currency in panicky movements. Such flows of capital can throw a country literally overnight into a crisis".

${ }^{8}$ There are indications that this cost is high for India as well. See Jha (2002).
} 
excessive volatility in exchange rates would lead to a more efficient transformation of savings into investment and, hence, higher growth.

In terms of the practical details of the CTT - several authors have argued that the original Tobin proposals would need to be amended. Spahn (1996) argues that Tobin's original scheme of a uniform tax on all foreign exchange transactions could create liquidity problems for the day-to-day operation of financial markets while not being effective in case of strong speculative forces. He proposes a two-tier tax with a small tax under normal circumstance rising to high levels in case of excessive volatility symptomatic of a speculative attack: while a tax would apply to all foreign exchange transactions and to all financial transactions taking place in the secondary market of financial derivatives at a normal rate of $0.02 \%$, a special exchange surcharge would be levied in periods of excessive exchange rate turbulence. A source-based taxation as opposed to a residence or nationality-based tax is proposed. Schmidt (1999) argues that the implementation of a Tobin-type tax is technically feasible, provided that the tax is levied at the level of centralized payments systems. This system is also used for interbank foreign exchange transactions and has details of all gross transactions in its electronic transfer systems. Schmidt also suggests that implementation of the tax by offshore financial centres can be enforced because of the strong links between developed countries' central banks and offshore netting systems and securities exchanges. Central banks would act as tax collectors, making a new international institution for collecting tax proceeds unnecessary 9 .

A variant of the CTT is the Cross Border Capital Tax (CBCT) proposed by Zee (2000). The transaction taxed here is gross capital inflow in the capital account of

\footnotetext{
${ }^{9}$ Although a universal CTT would be most suitable, there appears to be considerable opposition to its implementation in the US and the UK - ironically the two countries that stand to gain the most revenues from an implementation of the tax. In this context Spahn, Schmidt and several others have been arguing in terms of a EU plus Switzerland (henceforth EUS) tax.
} 
levying country. In the form that the tax has been proposed there is no need for international cooperation since each country would be levying the tax by itself. However, in operational terms, given their need for capital inflows most developing countries would be disinclined to impose this tax on their own. There would be a need to impose some degree of harmonization across countries.

Accord to the IMF's World Economic Outlook, 2002, net capital inflows into developing and transition countries alone are likely to exceed \$156 billion in 2002. For the world as whole gross capital inflows are likely to be much higher. A tax of even $1 \%$ could annual net revenues in excess of $\$ 2$ billion. However, a general tax applied universally is unlikely to have differential effects on capital flows and, is therefore, unlikely to help reduce exchange rate volatility.

To sum up, then, the regulation of global financial markets is as urgent as it is difficult. In fact almost no one argues that current regulatory arrangements for international finance are satisfactory. Efficiency problems include (a) deficiencies in data and their tardy publication; (b) an inexorable trend towards concentration and monopoly in global financial markets raising issues of excess profit, reduced incentives to innovation and consumer protection; (c) much contemporary global finance is unrelated to the exchange of real goods and services and is largely selfreferential where finance becomes an end in itself rather than a means to general material betterment; (d) there is the issue of uninternalized externalities from excessive capital flows. It is simply spurious to argue - as the most diehard advocates of the liberal order would - that global financial flows are efficient and that regulation of global financial markets would reduce efficiency. Even derivative markets that are supposed to act as a deterrent to the CTT have had their share of problems including the Metall Gesellschaft and Orange County Affairs in 1994, Barings in 1995, 
Sumitomo in 1996 and Long Term Capital Management in 1998. Against this background a CTT type measure may actually turn out to increase the efficiency of global financial markets as well as collecting substantial revenue for development aid.

\section{II.3 Aviation Taxes}

Several versions of this tax have been suggested. These include: (i) an aviation fuel tax. (Sometimes defined as a tax on kerosene.); (ii) a charge on air travel added on to the cost of the ticket; (iii) a fee for airport use (already in place in some countries such as Sri Lanka) (iv) user charge based on emissions.

The revenue potential of an aviation fuel tax is quite substantial. Fuel costs in 1998 were estimated to be about $\$ 50$ billion per year in 1998. A tax rate of about $25 \%$ on this would helve the rate of growth of fuel use, but not affect demand very much according to IPCC (2001). IPCC estimates revenues of about $\$ 12.5$ billion per year from this. Bleijenberg and Wit (1998) estimate that worldwide consumption of kerosene for civil aviation in 2015 will be 255 to 417 billion litres. Even a small tax on this would yield substantial revenues. Lufthansa (2002) estimates that at present the consumption of kerosene per 100 passenger-kilometres in Europe varies between 3 and 10.5 litres. Kerosene along with other components of aviation fuel contributes toward emission of carbon dioxide, nitrogen oxides, carbon monoxide, hydrocarbons, water vapour, sulphur oxides and aerosol particles. Lee et. al. (2001) estimate that energy consumption of the fleets in service will fall annually by only $1-2 \%$ on account of technological improvements while demand for air transport will grow by $4--6 \%$ per year. Thus taxing such fuels would have important environmental benefits as well. Even though airplane travel currently accounts for only about 3\% of global carbon emissions, the IPCC (1999) estimates that it would amount to $15 \%$ by 2050 . 
Another variant of the aviation tax is a ticket levy. This necessitates imposing a surcharge on the price of all (international) passenger/freight flights as a charge on the use of airspace - a global common. This surcharge may be in the form of a fixed nominal amount, a percentage increase of the existing price or a percentage charge graduated according to kilometres. (WBGU (2002)). Such a ticket levy would be relatively simple to implement and would be collected by the airlines themselves. ICAO (2000) estimated that turnover in worldwide civil aviation would be 328.7 billion euros in 2002. It estimated that allowing for adjustments ${ }^{10}$ in demand for flights in response to higher prices, this would generate annual revenue of 10-16 billion euros. Although, at the present time, any form of taxation of air travel would have the effect of reducing demand for an industry that is already in considerable financial difficulties, IPPC (1999) and Lee et. al. (2001) estimate that future demand for air transport is likely to be buoyant. Between 1990 and 2050 the proportion of the total volume of passengers choosing to travel by air is expected to quadruple from $9 \%$ to $36 \%$. Increases in airfreight are likely to be comparable, at the very least.

A ticket levy has the added advantage that existing international aviation laws already permit it (WBGU (2002)). For instance, Norway, has applied a "green" levy on all national flights for which there is an alternative by rail and on all international flights originating from Norway since 1 January 1995. (Bleijenberg and Wit (1998)). Some developing countries might oppose this tax because its use might reduce tourism traffic, ceteris paribus. Enlisting their support requires proper earmarking of revenues for transfers to these countries.

A further avenue for aviation taxation is the graduated emissions levy. (Brockhagen and Lienemeyer (1999)). This levy would be calculated on the volume

\footnotetext{
${ }^{10}$ Bleijenberg and Wit (1998) and Oum et. al. (1990) estimate the price elasticity of holiday air travel to be $-0.4 \%$ to $-1.2 \%$ whereas business travel is less elastic at $-0.4 \%$ to $-1.2 \%$. The elasticity of freight traffic lies between these two values $(-0.8 \%$ to $-1.6 \%)$.
} 
of main environmental impacts induced by aviation for different aircraft types, as a function of the number of seats and capacity utilization (and thus weight) and distance. The preferred method would involve assessment of carbon dioxide ${ }^{11}$, of contrails ${ }^{12}$, and ${ }^{13} \mathrm{NO}_{\mathrm{x}}$. On the basis of this Brockhagen and Lienemeyer (1999) arrive at estimates of the levy on domestic and international travel as a function of distance travelled for three different types of aircraft: Boeing 737, Airbus A300 and Boeing 747. Under their assumptions with an average load factor of $67 \%$ the emission charges range from 3.9 euros to 140.9 euros for domestic flights and between 1.9 euros and 70.4 euros for international flights. Revenue estimates are comparable to those for levy from kerosene levy.

A final aviation-related could be the international auctioning of emissions permits for polluting airspace. WBGU (2002) argues that if such permits are auctioned globally and annually the revenue generated will be similar to that from an emissions levy - say a kerosene levy. In 1998 airport use charges in the US alone amounted to $\$ 6.7$ billion.

The IPCC is the major proponent of aviation taxes and levies. Other advocacy groups include WBGU (2002), environmental lobbies such as Friends of the Earth. The Dutch EU presidency (January - June 1997) was instrumental in bringing discussion on this tax at the EU level. In 1998 OECD Environment Ministers agreed to the principle that "as far as possible (the prices of natural resources) should reflect the true environmental and social costs of production, consumption and scarcity".

\section{II.4 Email/Internet Taxes (The Bit Tax)}

\footnotetext{
${ }^{11}$ Burning $1 \mathrm{~kg}$. Of aviation kerosene forms about $3.2 \mathrm{~kg}$. Of CO2.

${ }^{12}$ This is roughly proportional to kerosene consumption.

${ }^{13} \mathrm{NO}_{\mathrm{x}}$ depends upon flight, altitude, distance, aircraft type and engine type.
} 
The base of this tax is the amount of data being sent through the internet. According to one proposal a person sending 100 emails per day with a 10-kilobyte document would pay a tax of just one cent. The revenue potential of this tax is quite substantial - UNDP (1999) estimated that this tax would have yielded $\$ 70$ billion in 1996 . Thus UNDP is a major advocate of this tax as is Soete (2002). At the rate at which this tax is proposed to be imposed it is unlikely to be a serious deterrent to the growth of the internet, particularly since indirect taxes such as the VAT are routinely evaded in many transactions conducted on the internet. In 1998 the apprehension that this tax might lead to a slowdown of the growth of the internet, led then US President Bill Clinton to successfully advance a proposal for the abandonment of internet taxation. If tax proceeds were used to bridge the "digital divide" between rich and poor nations this would actually help the growth of the internet.

\section{II.5 Tax on World Trade}

This would be a tax on world trade (exports + imports). An international organization such as the World Development Organization (WDO) proposed below would be responsible for the collection of this tax. The revenue potential of this tax would depend upon the response of international trade to the imposition of this tax. According to WTO (2001) world trade in 2000 was $\$ 6.2$ trillion. Assuming an elasticity of $5 \%$ in response to a $1 \%$ tax this tax would have yielded $\$ 58.9$ billion in revenue in 2000. Given that, in recent times, world trade growth has generally outpaced world GDP growth, tax yields would be quite buoyant during periods of high economic growth.

This tax was first proposed by the Brandt Commission as part of the proposal for a new international economic order. Enthusiasm for it has been lukewarm since. 
To the extent that the tax would also lower trade emanating from developing countries, it would adversely affect their growth, ceteris paribus. However, the tax would be progressive given the far greater concentration of international trade in OECD countries. Furthermore, the yield from this tax would more than compensate developing countries for this loss.

\section{II.6 Tax on Arms Sales}

The base of this tax is the value of all international arms sales. The international arms trade was worth $\$ 25-30$ billion during 1999-2000. Thus revenue from a 5\% tax would be in the range of $\$ 1$ to $\$ 1.5$ billion, assuming some reduction in arms trade because of the tax.

This tax has been proposed and supported by several UN agencies including the UNEP, the UN Committee on Development Planning, the Brandt Commission and the UNDP. To the extent that the tax would reduce international arms trade it would contribute to a lowering of tension. However, countries may not be willing to disclose complete statistics on arms trade for security reasons.

\section{7 Fees for Using the Global Commons}

There are several proposals for taxing the use of global commons, e.g., taxation for heavy use of oceans, the atmosphere, and the geostationary orbit for parking of satellites. Several UN agencies and environmental groups have made these proposals.

For some of these commons estimates of yields from user charges have been made. I have already commented on proposals for an aviation tax. I briefly comment on the prospects for charging for use of seas and oceans for transport. Ship owners 
already pay for the use of fairways and docks. Such fairway and harbour charges are generally meant for maintenance of harbours and associated infrastructure. Some authors, e.g., WBGU (2002), have proposed levying a tonnage and pollution charge, which would allow for credits for reducing pollution by ships. The proposal aims at relating the charge to the deadweight carrying capacity of ships measured in tonnes deadweight (tdw). This would have the added environmental advantage that ships with the highest deadweight carrying capacities have the largest which leads to more dredging work. The disposal of such dredging work causes environmental damage. Hence charges for tankers and bulk cargo freighters would depend upon ship size. To make the charges more sensitive to environmental impact of shipping we could take account of the ship's engine power in $\mathrm{kW}$ as ships since larger engines cause more environmental damage. Since parcel and regular service ships have relatively low tdw values but more power than tramp and bulk cargo ships, the lower tdw values will approximately be balanced out in the total calculations. Since parcel and regular service ships carry more valuable loads at far higher rates, higher charges for more powerful ships are acceptable. The proposed formula has a structure that is proportional to tdw and $\mathrm{kw}$. Thus

Base charge $(\$)=\mathrm{T}^{*} \mathrm{~F}_{1}+\mathrm{P} * \mathrm{~F}_{2}$

Where $\mathrm{T}=$ deadweight tonnage, $\mathrm{F}_{1}=$ Factor $1(\$ / \mathrm{tdw}) ; \mathrm{P}=$ Engine Power $(\mathrm{kW})$ and $\mathrm{F}_{2}$ $=$ Factor $2(\$ / \mathrm{kW})$.

As per ISL (2001) there were a total number of 55,233 sea-faring vessels on January 1, 2001 with an average tonnage of 9855. Assuming an average engine power of $18000 \mathrm{~kW}$ and $F_{1}=F_{2}=50$ cents, we get the 2001 revenue figure of just over $\$ 769$ million. Similarly one can also devise mechanisms for charging for 
parking satellites in the geostationary orbit and the like. Total revenues from such user fees could well be in billions of dollars annually.

\section{II.8 Additional Measures}

Another possible source of revenue for developing countries is the issuance of new SDRs to be transferred in large part to the poorest countries. When SDRs were first issued in 1973 they were a much larger proportion of world trade or world capital flows. A case can be made for catching up with a fresh issue of SDRs to be distributed in large part to the poorest among the developing countries. Support for this measure is likely to be limited. An allied measure is the sale of some of the IMF stocks of gold. Presumably the proceeds from this would go to help reduce the debt of HIPC countries or for IMF's Enhanced Structural Adjustment Facility. The IMF tried this proposal in late 1990 but had to abandon it in the face of opposition from gold producing countries who feared a drop in the price of gold. Thus there is insufficient political backing for this proposal.

Finally, there is also the option of recouping the loss to revenue authorities worldwide from the existing structure of global finance. This includes but is not confined to funds held in tax havens. Apart from denying governments due taxes, such governance arrangements for global finance have often sustained or even widened arbitrary inequalities of opportunity in the world economy between Northern and Southern countries. Around 60 jurisdictions across the world (including Bahrain, the Cayman Islands, Jersey and Singapore) now offer low taxation and high confidentiality that are geared toward high net worth individuals. Some estimates indicate that offshore banks now hold an estimated $\$ 5$ trillion in deposits that escape 
regimes of taxation and regulation. This is a global subsidy to wealthy people with no efficiency justification.

\section{Issues of Tax Administration}

We have so far outlined several important policy initiatives that could result in several tens of billions of dollars of revenue for development finance with only limited costs to the world economy and, in some cases, with considerable compensating benefits. However, the revenues would come from a number of sources and will be very skewed in their geographical origin. Furthermore, tax-collecting authorities would vary considerably - from customs officials to central banks to ICAO and others. The tasks of providing coordinating mechanisms for collection of such duties, organizing compensation for them, delineating projects to be funded, devising rules for disbursements of funds, ensuring accountability and other attendant responsibilities are challenging indeed.

To take just one example consider the administrative issues attending a CTT. It has to be decided where the tax is to be levied - when concluding a contract at the trading desk, when entering the trade into the books of accounts, or when the trade is finally settled. It should be clear as to who is responsible for withholding the tax and to whom the tax should be paid. Also the tax should be easy to administer and its effects on financial markets should be easily verified. Kenen (1995) proposed the tax be based at the trading desk. He argued that account books can be kept anywhere in the world and hence cannot form the basis for taxation. The point of settlement is ruled out since all claims are netted out at settlement so that the base of the tax will be low; and the national settlement systems may be unable to distinguish transactions in accordance with their underlying business. A transaction within Europe that corresponds to a purchase of the dollar by a firm may actually be done to settle a 
transaction denoted in dollars within Europe. Schmidt (1999), however, has argued that the tax be levied at the level of settlement (more precisely, payment). He discusses a number of improvements in the technology of settling foreign exchange transactions that make the settlement stage a better basis for taxation ${ }^{14}$. However, Spahn (2002) argues that Kenen's proposal also has merit in that the dislocation of trading desks to avoid the CTT could be quite costly. The "natural monopoly" of London because of its location and straight links to both Asian and American time zones is unlikely to be done away by the CTT. Thus there are merits to both proposals $^{15}$. With the high degree of centralization in settlement systems, Schmidt's method is likely to be administratively simpler. Although most countries have their own settlement systems for foreign exchange transactions, greater adoption of methods such as Real Time Gross Settlement (RTGS) increases the scope for imposing a successful CTT at the settlement stage.

Examples of complexity can be cited in the case of almost all the international taxes proposed. Since the UN is already quite stretched and the Bretton Woods organizations are geared towards completely different activities, it is quite clear that we need a new international institution to address this multitude of issues. We propose the establishment of an international organization tentatively called a World Development Organization (WDO) specifically geared towards these purposes. The WDO's agenda would be complex. It would first need to choose the taxes and levies to be imposed, set the tax rates, define the tax bases and coordinate tax

\footnotetext{
${ }^{14}$ Auditing to avoid tax evasion would be a problem. One level of auditing must be undertaken by national governments and is particularly crucial in the large financial centers. A significant amount of coordination - much more than what exists at the moment - among national tax authorities would be required. A second level of audit may be required to ensure that national governments effectively transfer the established proportion to their account with the international organization. A third level of auditing needs to be carried out to ensure that the expenditures of the tax are properly accounted for.

${ }^{15}$ With the development of the Continuous Link Settlement (CLS) there will be an international structure on the currency markets in the near future that could play a central role by taxing currency flows. This will further aid taxation at the level of settlement.
} 
collection across a number of institutions (from central banks in the case of the CTT to customs officials in other cases) and decide on how to compensate participating countries/authorities for expenses in tax and levy administration.

The WDO would then need to advance a cogent rationale for the remainder of the funds to be transferred to it to be spent on a pre-agreed program of development aid. In the standard theory of public finance when a tax (such as a carbon tax or a CTT) is imposed to correct for externalities the revenues are assumed to be distributed among the population in a lump-sum manner. Others have argued that the revenue raised from such taxation should permit a lowering of other distorting taxes such as income taxes or ad valorem commodity taxes if we aim for revenue neutrality. This is the notion of a double dividend associated with taxation of externalities - not only are harmful externalities lowered but also there is the prospect of lowering other distortionary taxes. If the WDO is to ask for these revenues to be used to augment aid flows, there must be a strong welfare argument to counter the welfare effects of the double dividend in the countries imposing the taxes.

Even in developed countries much of the revenue from (the national) taxation of environmental bads has been earmarked ${ }^{16}$ for spending on environmental cleanup (Fullerton (1996)). We are arguing instead that at least a part of such revenues be set aside to supplement foreign aid to developing countries - this is earmarking in a different direction.

Earmarking is unlikely to be optimal in terms of standard efficiency criteria. Why does it occur, then? Brett and Keen (2000) argue that earmarking may enhance

\footnotetext{
${ }^{16}$ This is even true in that epicenter of efficient taxation and pricing - the US - where the proceeds of a bewilderingly large number of environmental taxes are paid into a large number of trust funds that finance various clean up activities. Perhaps the best known of these is the Superfund, which has financed clean-up of damage from the production and disposal of chemical and petroleum products from an array of taxes on chemicals and petroleum.
} 
the efficiency of some voting processes. Politicians, if they retain some discretion in the ex post use of funds, may be able to divert the revenue raised by the tax to projects which they value but voters do not. Put at its crudest, politicians may simply take the money and run! In this case, a Pigovian tax may not be politically sustainable, because although (in a certain sense) ex post efficient, they expose the citizen to too much risk of expropriation by unscrupulous politicians. Political support for the tax itself would then be eroded by mistrust of its own spending aspirations. "The prevalence of earmarking” argues Goode (1984) “indicates a lack of confidence in the governmental system and the budgetary process". Earmarking may, hence, be essential even in the context of domestic economic policy. This would even more emphatically be true in the case of funds diverted to the WDO in view of the suspicion with which aid programs are viewed in developed countries.

Stated in its starkest form, the argument for earmarking is that much of the revenue from the taxes and levies proposed in this paper would accrue as a result of economic activity in developed countries, why should these countries divert these funds to an organization like the WDO? In line with the double dividend argument should these countries not use these revenues for reducing other distortionary taxes within their own jurisdictions? To push this argument a bit further: why is there so little enthusiasm for a tax such as the CTT in countries - such as the UK and the US that stand to gain the most from it in revenue terms?

Thus a cogent rationale for earmarking has to be central to the WDO agenda. To the extent that some of the international taxes and levies correct for externalities there will naturally be pressure to earmark some revenues for further reducing these externalities. Some part of the revenues from a carbon tax or an aviation fuel tax, for example, would have to be earmarked for developing cleaner technologies for 
airplanes, for example, and to financing adoption of cleaner technologies world-wide, not just in developing countries.

The WDO could build a rationale by pointing out that there are some obvious areas - redressal of urgent global bads - where targeted aid would prove invaluable. The programs covered could include (a) partial debt forgiveness for the poorest countries so that they can be on a self-sustaining part of economic growth without undue accumulation of foreign debt; (b) aid in recovery from shocks ${ }^{17}$ with strong hysteresis effects ${ }^{18}$ such as health shocks (HIV-AIDS, malaria, tuberculosis, waterborne diseases and the like which have a disproportionately high and persistent incidence on poor countries (Gallup and Sachs (1998)) ); (c) augmenting human capital; and (d) anticipating a drought and preventing the consequent hunger thus preventing a humanitarian crisis, which the world would have had to tackle. Payments towards such activities by individual developed countries or groups of countries are often difficult to negotiate and inadequate as is evidenced by the widespread disappointment with US aid pledges to combat HIV/AIDS in the recently concluded Barcelona conference. If such activities are financed by international taxes and levies the burden would be spread around and there may well be attendant advantages such as lowering greenhouse gas emissions or exchange market volatility. The WDO would require potential recipients among developing countries to provide an

\footnotetext{
${ }^{17}$ Collier and Dehn (2001) have highlighted the severity of shocks, and attendant hysteresis effects including terms of trade deterioration as well as shocks due to crop failures (partly a result of subsidy policy in developed countries). They indicate that much of the so-called countercyclical aid is inadequate and available with such a time lag that it ends up becoming procyclical. Hence, there exists a justification for establishing a developing country insurance fund that would provide buffers for developing countries facing adverse terms of trade shocks or crop failures and the like.

${ }^{18}$ The World Bank has been an active partner in the establishment of a Global Fund to fight AIDS, Tuberculosis and Malaria to help surmount the large financing gap necessary to win the fight against these diseases which cause nearly 6 million deaths each year. The Fund is an independent, publicprivate partnership working to increase global resources to combat these diseases, direct these resources where they are needed most, and ensure that these resources are used effectively. To date, about $\$ 1.9$ billion has been pledged. This is much too inadequate and contributions from the revenues from a CTT could be used to supplement resources.
} 
appropriate list of projects and a credible strategy ${ }^{19}$ for the use of such aid. A rationale for diversion of funds to the WDO in order to meet global and developing country needs would be complex involving agreement on the amounts to be transferred, the kinds and levels of insurance programs to be instituted, the monitoring mechanisms, the extent of funding for GPG, formulae for aid disbursal and others. These would be important constituents of the charter of the WDO.

\section{Disbursal of International Aid through the WDO}

The analysis so far indicates that operationalizing the disbursal of aid through the WDO would require agreement on two crucial elements. First, there needs to be a voting mechanism to decide on operational and procedural issues prior to the disbursal of program aid to developing countries. Some of these issues are: (i) deciding on the tax bases, levies, rates and the mix of these; (ii) deciding on compensation to be paid to national tax authorities, central banks, international agencies and other tax and fee collecting authorities; (iii) deciding on how much funds to earmark for objectives - such as improvements in environmental technologies - that are not purely developmental in nature; (iv) monitoring expenditure and receipt flows and identifying problem areas; and (v) deciding on the amount of funds to be set aside for transfer as aid to developing countries. This could take two forms. First, there would be a basic minimum to be spent on redressing global public bads emanating from the poorest developing countries. Thus partial debt writeoffs for the poorest countries, funds for controlling epidemics and diseases and

\footnotetext{
${ }^{19}$ As is well-known under their HIPC initiative the IMF and the World Bank have insisted on "Poverty Reduction Strategy Papers (PRSP)" . This requirement has been criticised because the most severely indebted countries need debt relief first and foremost to put their budgetary processes in order and because they are ill equipped to prepare such PRSP. The aid that is being considered here comes after debt writeoff and insurance schemes have been put in place. Hence these are not subject to the same criticism.
} 
enhancing human capital and partially compensation for terms of trade deterioration ${ }^{20}$ would be important. The second component would be program aid for developing countries. The voting mechanism suggested below addresses these issues and, hence, fixes the size of the program aid budget for developing countries. The second issue to be addressed is a formula to decide upon the distribution of the program aid budget of the WDO.

The voting structure to decide upon issues relating to the WDO operations could have the following arguments: (a) amount of contribution to the WDO, relative to total contributions; (b) some measure of size of the country - say its GDPPPP (GDP in PPP terms) or population; and (c) rewarding of good macroeconomic management ${ }^{21}$. Suppose total votes within the WDO are 10000 . We distribute these votes among the members of the WDO as per (2):

$$
V_{j}=10000\left[\theta_{1} \frac{C_{j}}{\sum_{j} C_{j}}+\theta_{2} \frac{S_{j}}{\sum_{j} S_{j}}+\theta_{3} \frac{E_{j}}{\sum_{j} E_{j}}\right]
$$

$\mathrm{V}_{\mathrm{j}}$ is the vote of country $j, \mathrm{C}_{\mathrm{j}}$ is its contribution to the WDO funds, $\mathrm{S}_{\mathrm{j}}$ is its GDPPPP, and $E_{j}$ is the value of its macroeconomic performance index relative to that of the US (the value of this index for the US is normalized to one). For any particular year this index is defined as the five year moving average $\mathrm{e}^{22}$ of macroeconomic performance consisting of a) government deficit as a percentage of GDP, b) current account as a percentage of GDP, c) inflation; d) rate of growth of real GDP per capita.. Fiscal deficit, current account deficit and inflation are undesirables and could carry a

\footnotetext{
${ }^{20}$ Most of these are global public bads in only an incomplete sense. For instance, it could be argued that terms of trade deterioration are the result of the market mechanism and should not be counted as a global bad. However secular terms of trade decline over a long period have led several developing countries into difficult external payments situations from which many of them have fund themselves impossible to extricate.

${ }^{21}$ The necessity of building such incentive structures in voting formulae has been discussed by Jha and Saggar (2000).

${ }^{22}$ This would help smoothen fluctuations in these magnitudes.
} 
negative weight with equal absolute value each. Growth of real per capita GDP and could be given a positive weight equal to the sum of the weights on the government deficit, current account deficit and inflation. The summation, in the case of each argument on the RHS of (2), is over all members of the WDO. The weights $\theta_{\mathrm{k}}$ are each positive with $\theta_{1}+\theta_{2}+\theta_{3}=1$ and typically $\theta_{1}>\theta_{2}>\theta_{3}$. Hence this formula gives highest weight to the contributions of a country, then to its size and builds in an incentive mechanism for improving macroeconomic efficiency ${ }^{23}$. A large majority need not be needed to pass proposals -perhaps a $60 \%$ majority ${ }^{24}$ would be adequate for the purposes of the $\mathrm{WDO}^{25}$.

We now address the question of disbursal of general program aid to developing countries. This is an area fraught with difficulties but some light on this can be shed from the intergovernmental grants literature (Wildasin (1997), Jha (1998) and Bird and Smart (2002)). Typically intergovernmental grants structures are designed to satisfy several criteria - allocative efficiency, macroeconomic stability, need, and encouraging local revenue generation effort. Arguments in support of particular formulae attempt to bridge (i) vertical fiscal imbalance. This requires that the normalized revenue and expenditure for each lower level of government are approximately equal. (ii) Horizontal fiscal imbalance. This is the foundation for the well-known equalization grants. Such grants are broadly based on the principles of (a) need, (b) capacity; and (c) effort of the local government. "Need" is typically proxied by some combination of population and the form of local government. Capacity is an indicator of the amount of revenue that the lower level of government is capable of

\footnotetext{
${ }^{23} \mathrm{I}$ am grateful to Matthew Odedokun for help in articulating this formula.

${ }^{24}$ The political economy of the design of global institutions of this variety is outside the scope of this paper. For some insights see Kormenos, Lipson and Snidal (2001a, 2001b). Essentially this argument hinges on the Folk Theorem which says that in infinitely-repeated games incentives for cooperation will ultimately appear. What is left out is whether the cooperation will be "sufficient". See Jha (1998, chapter 6) on this point.

${ }^{25}$ See also Paul and Wahlberg (2001).
} 
raising. Effort is an indicator of the effects of the grant on the incentive structure of the lower level of government to raise revenue

Applications of such principles to intergovernmental grants are problematic in themselves. These problems get aggravated when such principles are to be extended to international transfers through a WDO. However, some general principles can be enunciated. First, only countries with per capita GDPPPP below a certain threshold level would be eligible for such grants. Second, ceteris paribus, "need" is to be established as a combination of population and per capita income in PPP terms. One would need to develop an index of such need. Third, the capacity to raise own resources can be ascertained in terms of factors such as tax/GDP ratios. Developing countries with tax/GDP ratios below the median for the group should be deemed to have low tax capacity and be eligible for additional funds. However, this structure of grants should be encouraging of improving tax effort. If the moving average of the trend in tax/GDP ratio for any given country is rising even though the absolute level of the tax/GDP ratio of this country is below the median, this country should be deemed to improving tax effort and be rewarded by additional funds. All countries must present credible plans of reforms that could lead to enhanced macroeconomic stability and improving tax/GDP ratios to qualify for such grants ${ }^{26}$. A possible formula for the disbursal of such aid could look like the following:

$T R_{i}=\alpha_{1}\left[\frac{\left(P O P_{i}\right)^{\beta 1}}{\left(G D P P C P P P_{i}\right)^{\beta 2}}\right]+\alpha_{2}\left[(\right.$ mediantax $\left./ G D P)-(\operatorname{tax} / G D P)_{i}\right]+\alpha_{3}\left(T R 5_{i}\right)$

where $\mathrm{TR}_{\mathrm{i}}$ is points ascribed to country $i, \mathrm{POP}_{\mathrm{i}}$ is its population, GDPPCPPP $\mathrm{i}_{\mathrm{i}}$ its GDP per capita in PPP terms, mediantax/GDP is the median tax/GDP ratio of the countries

\footnotetext{
${ }^{26}$ As Fiszbein (1997) and Faguet (2001) show, there is strong evidence in some countries that even some poor areas may mange surprisingly well if they are enabled and encouraged to do so.
} 
that are being considered for the transfers, $(\operatorname{tax} / \mathrm{GDP})_{\mathrm{i}}$ is the ith country's tax/GDP ratio and TR5 $5_{\mathrm{i}}$ is the 5 -year moving average of the trend in tax/GDP ratio of country $i$. Given any aid budget the transfer to country $j$ is simply $\frac{T R_{j}}{\sum_{j} T R_{j}}$ multiplied by the total program aid of the WDO. The summation in the denominator of the above expression is over all developing countries that are to be given aid. All parameters are defined to be positive. Transfers to a country are positively related to its population and negatively related to its GDPPCPPP. The weights on these magnitudes can be different. A country with tax/GDP ratio lower than the median would get additional grants, as would a country that is improving its tax/GDP ratio over time. The weight structure in this formula could be the subject of some debate. One could argue that $\beta_{2}$ $>\beta_{1}$, i.e., the negative weight on GDPPCPPP outweighs the positive weight on population. This is because the grant structure would like to target the poorest countries. Further typically one would argue that $\alpha_{1}>\alpha_{2}>\alpha_{3}$. The weight on the "need" factor should be greater than that on the "capacity" factor which, in turn, should be greater than that on the "effort" factor. What magnitudes one would place on them would, essentially, be a matter of negotiation within the WDO and no $a$ priori judgement can be made ${ }^{27}$.

\section{Conclusions}

The Ernesto Zedillo committee had set the target of garnering an additional \$50 billion per year in development finance. The present paper has considered various options for generating funds substantially in excess of this amount with only limited

\footnotetext{
${ }^{27}$ Jhe et. al. (1999) provide a formal way to quantify tax effort and demonstrate the effect of this on tax capacity at the sub-national level.
} 
costs for the global economy and, in some cases, with attendant compensating advantages.

We have also provided estimates of revenue from such taxes/levies and argued that there is a need to develop a rationale for earmarking a portion of the revenues from these taxes for disbursal as aid to developing countries. Further, given the complexities of organizing and administering such taxes an international authority (called the WDO) would be necessary. The WDO would be responsible for administering the taxes and organizing the distribution of the proceeds.

A major obstacle to such sweeping international reform is the lukewarm attitude of the US. Led by Senator Helms, US payments to the United Nations are now conditional upon the UN abandoning efforts which "develop, advocate, promote, or publicize proposals" that impose taxes or fees on US citizens. But there is evidence both within the United States and the international community, of vibrant support for various forms of global taxation. ATI Foundation opinion polls indicate high approval ratings in the US for a $0.5 \%$ tax on international currency trades $(69 \%)$ and for a tax on carbon combustion emissions (79\%)..Support for internationally levied charges is particularly strong within the European Union, where common policies and measures are being pursued on a variety of issues. A growing body of official EU policies supports the use of environmental taxation and a reduction in labor and capital taxes (a so-called tax shift, or environmental tax reform, ETR). Citizen groups and NGOs are also active in the debate, lobbying governments and international organizations to adopt regional or global taxes. The weaknesses of the current system, based on voluntary contributions, are becoming increasingly apparent, and global levies could ensure that developing countries receive some of the funds that have been promised, but not forthcoming. Developed countries could also support such global levies for 
this reason - no longer would they need to push through politically difficult appropriations bills for ODA or UN dues. Funding from international sources could at least ease the pressure to appropriate domestic tax revenues for international purposes.

The current governance of global finance is piecemeal and there is evidence that it has not encouraged enhanced resource transfers to developing countries as an objective. It is important to keep this in mind and to conceive of global taxes and levies only as part of an overall international institutional arrangement designed to facilitate a conducive climate for poverty alleviation and rapid economic growth in the poorest countries. 


\section{REFERENCES}

Bank for International Settlements, (2002) Triennial Central Bank Survey: Foreign exchange and derivatives market activity in 2000, Basel, Switzerland. www.bis.org

Bank for International Settlements, (2001) 'Central Bank Survey of Foreign Exchange and Derivatives Market Activity in April 2001: Preliminary global data', Press Release, 9 October, Ref. No. 31/2001E, Basel Switzerland.

Bird, R. and M. Smart (2002) 'Intergovernmental Fiscal Transfers: International Lessons for Developing Countries' World Development, vol. 30, no.6, pp.899912.

Bleijenberg, A. and R. Wit (1998) 'European Environmental Aviation Charge Feasibility Study' Delft: Centre for Energy Conservation and Environmental Technology.

Brandt Commission (1980) Report of the "Independent Commission for International Developmental Issues" (the "North-South Commission) New York: United Nations.

Brett, C. and M. Keen (2000). 'Political Uncertainty and the Earmarking of Environmental Taxes', Journal of Public Economics 75, pp. 315-40.

Brockhagen, D. and M. Lienemeyer (1999) 'Proposal for a European Levy to Internalise external costs of climate change' Delft: Centre for Energy Conservation and Environmental Technology, Mimeo.

Burnside, C. and D. Dollar (2000) 'Aid, Policies and Growth' American Economic 
Review, vol.90, no.4, pp.847-868.

Calvo, G. and C. Reinhart (2000) 'Fear of Floating' available on the website www.puaf.umd.edu/papers/reinhart/papers.htm

Chang, C.G., Fernandez-Arias, E. and L.Serven (1999) 'Measuring Aid Flows: A New Approach’ Policy Research Paper 2050, The World Bank, Washington, D.C.

Collier, P. and J. Dehn, (2001) 'Aid, Shocks, and Growth', October, mimeo.

Cooper, R. (1998) ‘Toward a Real Global Warming Treaty,' Foreign Affairs March/April, 1998 and 'Cleaner Energy', The Economist 18-24 April 1998:

Clunies-Ross, A.(2000) 'Resources for Social Development: Additional and Innovative Measures' DESA Discussion Paper No. 11, United Nations.

DAC (Development Assistance Committee), (1996) 'Shaping the $21^{\text {st }}$ Century: The contribution of development co-operation', Paris: OECD, May.

Dornbusch, R. (1976) 'Expectations and Exchange Rate Dynamics', Journal of Political Economy 84 (4): 1161-76.

Eichengreen, J., Tobin, J., and C. Wyplosz, C. (1995). 'Two Cases for Sand in the Wheels of International Finance', The Economic Journal 105(428): 162-72.

Eichengreen, B., 1999, Towards a New International Financial Architecture, Institute For International Economics, Washington, DC.

European Commission (2002) 'Responses to the Challenges of Globalization: A study on the international monetary and financial system on a financing for development', February. Available on 
http://www.globalpolicy.org/socecon/un/unctad/2002/0228euglobal.htm

Faguet, J. (2001) 'Does Decentralization increase government responsiveness to Local Needs?' World Bank Policy Research Paper No. 2516, Washington, DC: The World Bank.

Faust, M., Kaul, I. Goulven, K.L. Ryu, G., and Schnupf, M., 2001. Global Public Goods: Taking the Concept Forward, Discussion Paper Series, No. 17, Office of Development Studies, New York: United Nations Development Program (UNDP).

Fiszbein, A. (1997) 'Emergence of Local Capacity: Lesson from Colombia' World Development, vol. 25, no. 7, pp. 1029-1043.

Foster, J. (2002) 'Doing the Monterrey Shuffle: Donor countries “never richer, never meaner" as UN Financing for Development conference proceeds', NorthSouth Institute, Ottawa, March, mimeo.

Frankel, J. (1995) 'How well do Markets Work: Might a Tobin Tax Help?' in the Tobin Tax: coping with financial volatility, M. ul Haq, I. Kaul, and I. Grunberg, eds, New York \& Oxford: Oxford University Press.

Frenkel, J., (1999) 'No Single Currency Regime is Right for all Countries or at all Times', NBER Working Paper, 7338.

Fullerton, D. (1996) 'Why have separate environmental taxes?' in J. Poterba (ed.) Tax Policy and the Economy, Cambridge, MIT: MIT Press.

Gallup, J. and J. Sachs (1998) “The Economic Burden of Malaria” Centre for International Development at Harvard, Working Paper.

Global Policy Forum (2002) http://www.globalpolicy.org/finance/alternat/biblio/ 
Goode, R. (1984) Government Finance in Developing Countries, Brookings Institution: Washington, DC.

Griffith-Jones, S.(1995) 'Institutional Arrangements for a Tax on Foreign Exchange Transactions' in the Tobin Tax: coping with financial volatility, M. ul Haq, I. Kaul, and I. Grunberg, eds, New York \& Oxford: Oxford University Press.

Hansen, H. and F. Tarp (2000) 'Policy Arena Aid Effectiveness Disputed', Journal of International Development 12: 375-98.

Hansen, H. and F. Tarp (2001) 'Aid and Growth Regressions', Journal of Development Economics 64: 547-70.

Haq, M., Kaul, I. and I. Grunberg (1996) The Tobin Tax, New York: Oxford University Press.

High Level Group of Experts, (1997) 'Building the European Information Society for Us All', mimeo, European Commission.

ICAO (1999) 'International Civil Aviation Organization, Emission Trading is an Effective, Proven Policy tool for solving air pollution problems', Montreal, http://www.icao.org/icao/en/jr/5407.pdf

ICAO (2000) International Civil Aviation Organization, Annual Report of the Council, Montreal, http:///www/icao.org/icao.int/index.cfm

IPCC (1999) Intergovernmental Panel on Climate Change, Special Report on Aviation and the Global Atmosphere, IPCC,WMO/UNEP, Cambridge, New York: Cambridge University Press. 
IPCC (2001) Intergovernmental Panel on Climate Change, Climate Change 2001 Mitigation. Contribution of Working Group III to the Third Assessment Report of the Intergovernmental Panel on Climate Change, Cambridge,

New York: Cambridge University Press.

ISL (2001), Institut fur Seeverkehrswirtschaft und Logistik, "Charges on the use of the Global Commons" http://www.wbgu.de/wbgu sn2002 ex01.pdf

Berlin: WBGU

Jha, R. (2001) 'Macroeconomics of Fiscal Policy in Developing Countries' WIDER Discussion Paper 2001/71, Helsinki.

Jha, R. (2002) 'Downward Rigidity of Indian Interest Rates' Economic and Political Weekly, vol. 37, no. 5, pp.469-474.

Jha, R.. (1998) Modern Public Economics, London and New York: Routledge.

Jha, R. and M. Saggar (2000) 'Towards a More Rational IMF Quota Structure:

Suggestion for the Creation of a New International Financial Architecture'

Development and Change, vol. 31, no.3, pp. 579-604.

Jha, R., Mohanty, M., S. Chatterjee and P. Chitkara (1999) 'Tax Efficiency in Selected Indian States’ Empirical Economics, vol. 24, no.4, pp. 641-654.

Kaul. I., Grunberg, I. and M. Stern (1999) Global Public Goods, New York: Oxford University Press for the UNDP. 
Kenen, P. (1995) 'The Feasibility of Taxing Foreign Exchange Transactions', in the Tobin Tax: coping with financial volatility, Haq,M., I. Kaul, and I. Grunberg, eds, New York \& Oxford: Oxford University Press.

Kormenos, B., Lipson, C. and D. Snidal (2001a) 'The Rational Design of International Institutions' International Organization, vol. 55, no.4, pp.761799.

Kormenos, B., Lipson, C. and D. Snidal (2001b) 'Rational Design: Looking Back to Move Forward' International Organization, vol. 55, no.4, pp.1051-1082.

Lee, J., Lukachko, S., Waitz, I. And A.Schafer (2001) 'Historical and Future Trends in Aircraft Performance, Cost and Emissions' Annual Review of Energy and the Environment, vol. 26, pp.167-200.

Lufthansa (2002) 'Balance, Daten und Fakten' Issue 2001/2002. At http://www.lufthansa.com/dlh/downloads/Treibst-Flotte180601.gif. Cologne:Lufthansa.

Mendez, R (1995) 'Paying for Peace and Development', Foreign Policy, Washington, Fall.

Mendez, R. (1992) International Public Finance, New York: Oxford University Press.

Monterrey Consensus (2002) Draft text of the Monterrey Consensus, prepared by the Co-Chairpersons, with the assistance of the Facilitator, 19 January.

NAR (1996) "International Funds for Cross-Border Problems: Looking for the Big Money" on http://www.globalpolicy.org/socecon/glotax/general/bigmoney.htm 
Najman, D. and H. d'Orville, H. (1995) Towards a New Multilateralism: Funding Global Priorities - innovative financing mechanisms for internationally agreed programmes, Independent Commission on Population and Quality of Life, New York.

ODI (1996) Overseas Development Institute, "New sources of Finance for Development" ODI Briefing Paper 1/96, available at http://www.odi.org.uk/publications/briefing/odi_briefing196.html

OECD, (1996a) Implementation Strategies for Environmental Taxes, Paris.

OECD (1996b) Shaping the $21^{\text {st }}$ Century: The Contribution of Development Cooperation, Paris.

Oum, T., Waters, W. and J. Yong (1990) 'Concepts of Price Elasticities of Transport Demand and Recent Empirical Estimates: An Interpretative Survey' Journal of Transport Economics, vol. 26, no.2,, pp.139-154.

Paul, J. and K. Wahlberg (2001) 'Global Taxes for Global Priorities', prepared in conjunction with a roundtable on Global Taxes for Global Priorities, May 5, 2001 and published by Global Policy Forum, WEED and the Heinrich Böll Foundation, March 2002.

Renard, R. and D. Cassimon (2001) 'On the Pitfalls of Measuring Aid', Discussion paper No. 2001/69, United Nations University, WIDER, August,

Schmidt, R. (1999) 'A feasible Foreign Exchange Transactions Tax', North-South Institute, Ottawa, March, mimeo. 
Scholte, J. (2002) ‘Governing Global Finance’, CSGR Working Paper No.

88/02, Department of Politics and International Studies, University of Warwick, January, mimeo.

Soete, L. (2002) 'Reaction to European Commission, DGXIII Bit Tax Proposal Analysis', on http://meritbbs.rulimburg.nl/cybertax/response.html

Spahn, P. (1996) 'The Tobin Tax and Exchange Rate Stability', Finance and Development, 24-27, June.

Spahn, P. (2002) On the Feasibility of a Tax on Foreign Exchange Transactions, Report to the Federal Ministry for Economic Cooperation and Development, Bonn.

Tobin, J.( 1978) “A Proposal for International Monetary Reform” Eastern Economic Journal, vol.4, pp.153-159.

UNDP (United Nations Development Program) (1999) Reinventing Global Governance - for humanity and equity', ch. 5, Human Development Report 1999, pp. 97-114.

Vandemoortele, J. (2002) 'Are the MDGs Feasible?', United Nations Development Program, Bureau for Development Policy, New York, June, mimeo.

WBGU (2002), German Advisory Council on Global Change, Charging the Use of the Global Commons, Special Report, Berlin.

Wildasin, D. (1997) (ed.) Fiscal Aspects of Evolving Federations, Cambridge: Cambridge University Press. 
World Trade Organization, (2001), Global Trade Statistics.

Zee, H., (2000) 'Retarding Short-Term Capital Inflows Through Withholding

Tax’, IMF Working Paper WP/00/40, International Monetary Fund, March. 